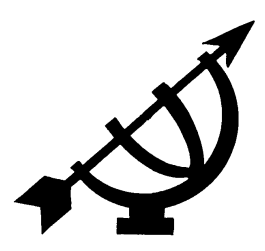

\title{
Work-family spillover revisited: Is there hope for marital happiness in the dual-earner family?
}

\author{
Ria Smit \\ Department of Sociology \\ Rand Afrikaans University \\ JOHANNESBURG \\ E-mail: rsm@lw.rau.ac.za
}

\begin{abstract}
Work-family spillover revisited: Is there hope for marital happiness in the dual-earner family?
\end{abstract}

In the past few decades social scientists have increasingly become aware of the dynamic qualities of gender and marital roles in the family. The changes taking place in terms of both the role contents and role behaviour of especially dual-earner couples have been identified as aspects affecting family life to a large extent. The increasing interface between the work and family spheres, based on the so-called work-family spillover model, has led to the conventional thesis that the non-traditional role behaviour of dualearner spouses and marital dissolution are causally related. The strenuous lifestyle associated with the dual-earner family may therefore have a detrimental effect on marital and familial relationships.

This article gives, in the first place, an overview of the dilemmas the dualearner family may be confronted with. In the second place, possible intervening or mediating variables that may come into play in the process of facilitating a work-family fit in the dual-earner family are discussed. Recent research suggests that these intervening variables may not only help dualearner families to cope successfully with strenuous dilemmas, but may even contribute to the experience of higher levels of marital integration and happiness.

\section{Introduction}

One of the most significant trends of the past few decades, manifesting world wide as well as in South Africa and affecting family life extensively, is the continuous rise in the rate of married women entering the labour market and subsequently the increase in the incidence of dual-earner families in society (Smit, 2000a:1; Edwards, 2001:186). As high demands 
are made on the time and commitment of the dual-earner couple, it stands to reason that the labour market participation of both spouses could have a profound impact on their marriage and family life. This may be due to the fact that the spouses' labour force participation could increase the possibility of conflict between work and family roles, since not only men but also women are increasingly defining their career role as an additional primary role. Carlson (1990:271) is in this regard, for example, of the opinion that "... career and family involvement have never been combined easily in the same person".

The increasing interface between work and family life has led to the conventional belief that married women's labour market participation and marital dissolution are causally related. This relationship may be explained by means of the work-family spillover model, stating that stress experienced in the work sphere may lead to a spillover effect into the family sphere and vice versa (Barnett, 1994:648; Paden \& Buehler, 1995: 101). In the light of the above, theorists such as Sekaran (1986) and Googins (1991) are of the opinion that the non-traditional lifestyle of the modern dual-earner family may result in the incidence of a number of challenging and sometimes strenuous dilemmas. The focus on these strenuous dilemmas has led, in my opinion, to the oversimplified conventional female employment-divorce argument, stating that “... the increases in labor force participation of [married women] have led to the higher levels of divorce in advanced societies" (Edwards et al., 1992:59). If this is the case, one can therefore ask the question: is there any hope for marital happiness in the dual-earner family?

In trying to answer this crucial question regarding the present and future quality of the dual-earner marriage, I turn to more recent studies where researchers are no longer concentrating only on the detrimental effects of the dual-earner family lifestyle. I am therefore suggesting a close scrutiny of research, such as that of Gelles (1995) and Smit (2000a), investigating intervening variables which may alleviate stress in the dualearner family and which may even contribute to an increase in the experience of marital integration and quality. In this article I shall not suffice to give only a brief overview of the stressful lifestyle of the dualearner family, but shall also focus on the possible intervening variables that may come into play in the process of facilitating a work-family fit.

\section{Stress in the dual-earner family}

In emphasising the existence of intervening variables I am, however, not negating the reality of the stressful non-traditional lifestyle of the dualearner family. The possible impact of these intervening variables on the 
marital relationship is rather shown in its true light against the backdrop of a discussion regarding the stress in the dual-earner family.

Due to the fact that an increasing number of women are these days perceiving their occupation/job as a second primary role alongside that of wife/mother, it may be said that there is an increase in the possible occurrence of inter-role conflict between the work and family roles. This higher incidence of the experience of role conflict and stress can be attributed to the competing demands made by the woman's different roles in regard to her limited resources with reference to time and energy. This view acts as primary impetus for the argument stating that the woman's labour market participation causes marital and familial disorganisation (Perry-Jenkins et al., 2000:986).

The woman's (non-traditional) role as labour market participant does not only bring about a quantitative increase in role obligations, but may also have a (negative) impact on the quality of her relationships with others in both the private (family) and public spheres. I would, however, also like to emphasise, in light of the rise in the ideology of the new fatherhood, that the same might apply to men who have taken on more responsibility regarding family activities traditionally associated with the role of the wife/mother. This may be attributable to the reciprocal spillover of negative, stressful feelings between the work and family environments (Sears \& Galambos, 1992:789). Consequently, the members of the dualearner family may be confronted with a number of strenuous dilemmas.

\subsection{The career-compromise dilemma}

On account of the fact that the dual-earner family is characterised by the condition that both spouses are actively involved in the labour market, the process of reaching an equitable compromise regarding the value attached to each of the spouses' jobs, can create a dilemma. According to Berger et al. (1978:23) the dual-earner couple strive for the ideal situation where both spouses have obtained working positions that will enable them to

- reside in the same geographical area;

- co-ordinate their daily schedules in such a way as to allow them to carry out both domestic and child-care task responsibilities;

- co-ordinate their schedules that will enable them to have time for both individual relaxation and leisure time with his/her spouse;

- obtain optimum satisfaction from their individual careers; and

- be satisfied with their long-term career objectives. 
In practice, however, it is not always possible to find the realisation of all the elements of this ideal-typical situation. This is especially true for career-orientated couples when career opportunities arise for one spouse while the other partner must make occupational sacrifices. This creates a situation where it is not only difficult for the spouses to reach a fair career compromise but which may also place strain on the marital relationship (Carter \& Carter, 1995:6). From a feminist perspective it is important to qualify that due to the prevalence of traditional patriarchal values in some families, women are usually the ones in dual-earner relationships who have less bargaining power when it comes to furthering their careers and who are sometimes compelled to forego career-related advancements.

Apart from the career compromise dilemma, the dual-earner couple may be confronted with a set of dilemmas that affect the husband-wife relationship extensively.

\subsection{Husband-wife relationship dilemma}

The dual-earner couple may experience a relationship dilemma as a consequence of the husband's attitude towards his wife's participation in the labour market. Whenever the husband has a negative or an apathetic attitude towards his wife's career involvement, she may interpret his attitude as one of denying her the opportunity to emulate this traditional a-typical female role. The husband's negative attitude may also be accompanied by his unwillingness to adapt to the changes that are brought about by a dual-earner family lifestyle (Holmstrom, 1972: 133). This may especially be a problem in unconventional asymmetrical marital relationships, where the wife has a higher financial income and/or a higher level of education (Safilios-Rothschild \& Dijkers, 1978:62).

In addition to the husband's possible negative attitude towards his wife's labour-force participation, researchers such as Cook (1992:204) and Wilkie et al. (1998:577) state that, notwithstanding the fact that husbands have become slightly more involved in household activities traditionally associated with the role of the wife, the working married woman is still responsible for most of the domestic and child-care responsibilities. This disparity in the allocation of household responsibilities is not only evident in countries such as the USA (Menaghan \& Parcel, 1990:1085; Benokraitis, 1996:266) and Canada (Brayfield, 1992:25), but is also prevalent in South Africa, as seen in the research of Maconachie (1992:115) and Smit (2000b:83).

Combined with the manifold demands of the woman's occupational role, these husband-wife relationship dilemmas may lead to high levels of role 
overload and marital conflict (Kluwer et al., 1997:648). The spouses in the dual-earner family are not only confronted with husband-wife relationship dilemmas, but are also exposed to the possible experience of stressors relating to parenthood.

\subsection{Parenthood dilemma}

The dual-earner couple may experience feelings of guilt based on arguments by theorists such as Belsky and Eggebeen (1991:1083) that the mother's occupational involvement may have a negative impact on her children. The dual-earner couple is, furthermore, confronted with arguments regarding the so-called absent father syndrome which, according to Biller (1995:74), may have a negative influence on a child's self-esteem and intellectual and social proficiency.

This experience of guilt may escalate in cases where the parents cannot afford the high financial costs of professional child-care facilities. Moen $(1992: 90)$ is of the opinion that in situations where parents, due to logistical and/or financial reasons, cannot make use of professional childcare facilities, and thus have to rely on the help of family members and non-professional child-caretakers, parents may experience intense feelings of distress regarding their children's physical, mental and psychological development and well-being.

\subsection{Social network dilemmas}

Due to a tight time schedule it is sometimes difficult for dual-earner couples to sustain ties with an extensive social network. This may create feelings of animosity on the part of friends and kin (Sekaran, 1986:187). It may also be the experience of these couples that members of their social network are critical of the non-traditional lifestyle of the dual-earner family. As also voiced by Wiersma (1994:213), I would like to emphasise that the decline in the quantity and/or quality of social network ties is paradoxical insofar as the dual-earner family, with its strenuous lifestyle, needs the support of significant others all the more.

\subsection{Role overload dilemma}

Due to the multiple role demands in both the work and family spheres, the dual-earner couple's experience of role overload may be unavoidable. This role overload is not only the consequence of the numerical increase in role-obligations, but it is also related to the duality of emotional commitment to a multitude of sometimes conflicting role demands (Jordan et al., 1989:30; Benokraitis, 1996:395). 
The role-overload dilemma can become even more problematic in cases where one or both the spouses are involved in a so-called greedy occupation (Handy, 1978:37). Individuals in these occupations are expected to be highly committed, not only to their jobs per se, but also to the larger organisation. Among the demands made by these occupations are long working hours, periodic geographical separation from the family and a constant preoccupation with work-related issues, which may lead to an escalation in marital tension (Pittman, 1994:207; Smit, 2000b:79).

\subsection{Time management dilemma}

When both spouses are employed full-time, their work-schedule rigidity may impede their ability to accommodate family-related responsibilities in their tight time schedules, resulting, according to Barnett (1994:648), in possible negative spillovers from the work to the family sphere. Although both spouses may experience this so-called "time crunch" (Crouter et al., $1987: 431$ ), it is especially the working married woman who finds herself vulnerable to this dilemma. Hantrais (1990:150) says in this regard that:

The price paid was the lack of personal time and the feeling of guilt if (an unusual occurrence) any free time was not used to be with children. Most women consequently found that they have to forego their own free time and, in some cases, reduce the amount of sleep they had, so that their children did not 'suffer' from having a working mother.

The problematic result is that the working married woman, due to a lack of relaxation, may experience an accumulation of strain that can once again have a negative impact on her marital and familial relationships (Carter \& Carter, 1995:9).

\subsection{Physical and mental health dilemma}

Although some theorists such as Moen (1992:52) argue that career women enjoy better health than women who do not participate in the labour market, other theorists are of the opinion that working married women do not only place their own health at risk, but also that of their families. Numerous studies indicate for example the relationship between occupational stress and the incidence of psychosomatic ailments such as hypertension, chronic fatigue, eating disorders, cardiovascular diseases and peptic ulcers (Davidson \& Cooper, 1983:52, Long \& Kahn, 1993:185, Perry-Jenkins et al., 2000:986).

It seems, however, that it is not the woman's occupational involvement per se that has a profound impact on her own and her family's health, but rather the degree to which she may experience role overload and role 
conflict as a result of combining a multitude of roles (Googins, 1991:135, Long \& Kahn, 1993:185).

Contradicting research results also exist regarding the relationship between job-related stress and the dual-earner couple's emotional and mental well-being. According to Sekaran (1986:45) and Carter and Carter (1995:102) wives with professional careers fall in a high-risk category when it comes to the quality of their mental health. McGrath et al. (1993:86) note in this regard that: "Despite the obvious advantages of professional status, career women appear to struggle with a variety of conflicts and stressors ... and have a higher incidence of depression and suicide than women in the general population."

Linked to the quality of mental health, is the importance of the way in which the spouses view themselves with regard to their different family roles.

\subsection{Role-identity dilemma}

If the spouses in the dual-earner family have internalised the traditional gender ideology, they are more likely to experience the role-identity dilemma as a result of the conflict between their traditional gender-role orientation and their non-traditional dual-earner family lifestyle (Sekaran, 1986:7). A man with a traditional gender-role orientation would for example be less willing to be responsible for those domestic and childcare responsibilities traditionally associated with the role of wife/mother. As a result conflicts may arise due to the incongruence in the expected, preferred and enacted behaviour within the context of the dual-earner family (Greenstein, 2000:323; Smit, 2000a:100).

It thus seems clear from a symbolic interactionist perspective that because of the individual's blurred role-identity it may be difficult for the person to define the nature and contents of the expected role behaviour vis-à-vis his/her spouse and children. Consequently, although the spouses may try to bring about a marital relationship based on egalitarian principles, they occasionally tend to revert back to the stereotypical gender and marital role values. This state of affairs may have a negative impact on the conjugal relationship.

\subsection{Normative dilemma}

The normative dilemma arises as a result of an incongruence between society's traditionally imposed gender and family-related values and the non-traditional lifestyle and role behaviour of the dual-earner family (Sekaran, 1986:188). 
I find that the normative dilemma is best illustrated by the following: During the 1980s and the years that followed an ambivalent attitude developed towards career-orientated married women. On the one hand there is still the prevalence of a disapproving attitude towards married women (especially those with pre-school children) who deviate from the traditional role as homemaker and primary child-caretaker. On the other hand, however, society gives its moral support to those women who would like to have it all. This is evident in the emphasis placed on the superwoman ideology as portrayed inter alia by popular woman magazines. Due to the fact that not all women are able to live up to the expectations of this idealised picture of the perfect wife, mother and employee, the feeling of role overload may be unavoidable to many, especially those who have an external locus of control (Sekaran, 1986: 188).

It would create a gender-biased picture if one does not emphasise that with the rise of the ideology of the new fatherhood, men in the dualearner family have increasingly become aware of the experience of the normative dilemma. The ambiguity surrounding the role of husband/ father is evident in the following words of Griswold (1993:244): "... fatherhood of recent decades has become a kaleidoscope of images and trends, a sure sign that it has lost cultural coherence ... fatherhood ... is now fraught with ambiguity and confusion. Not so surprisingly, so, too, are the fathers themselves".

The high incidence of families who experience the aforementioned dualearner family-related dilemmas is used by some theorists to substantiate the conventional belief that married women's employment and marital dissolution and even the formal termination of marital relationships are causally related (Edwards et al., 1992:59). According to this traditional argument, although not all dual-earner marriages end in divorce, the possibility does exist that the members of the dual-earner family might experience higher levels of stress and lower levels of marital integration in comparison to single-income families where the wives do not participate in the labour market.

Without denying the fact that the dual-earner family lifestyle may bring about the experience of stress and strain, I see the necessity for shifting the emphasis away from only focusing on the detrimental effects of this non-traditional family lifestyle, to the existence of intervening variables that may not only alleviate the stress in the dual-earner family, but which may also contribute to higher levels of marital quality. 


\section{Possible intervening variables}

In the discussion of the existence of possible intervening variables, I take as my point of departure the so-called mediation hypothesis. According to this hypothesis a number of intervening variables may contribute to the notion of a work/family fit, conceptualised as the perception of balance in the complex exchange between the work and family spheres. These intervening variables act, therefore, as mediators in the relationship between the labour market participation of both spouses and the experience of marital integration (Pittman, 1994:189). Based on an overview of diverse, relevant and subject-related literature, two sets of intervening variables can be identified, i.e. family-related and workrelated variables.

\subsection{Family-related variables: the husband-wife relationship}

The following number of variables, associated with the conjugal relationship, may have an impact on the dual-earner couple's experience of marital integration.

\subsubsection{The husband's attitude towards his wife's labour-market participation}

In contrast to marital relationships where husbands do not support their wives in their labour-market endeavours, both spouses experience higher levels of marital quality when the husband takes his wife's career seriously, is proud of her occupational achievements and display a general attitude of supportiveness (Vannoy \& Philliber, 1992:395). The husband's general attitude towards the family's dual-earner lifestyle manifests inter alia in his alacrity to become more involved in the household's day-to-day domestic activities.

\subsubsection{The husband's participation in domestic task responsibilities}

Theorists such as Benokraitis (1996:266), Wilkie et al. (1998:577) and Sandberg and Cornfield (2000:166) are of the opinion that, notwithstanding the fact that wives still bear the brunt of the preponderance of the responsibilities for domestic tasks, husbands have become slightly more involved in household activities that are traditionally associated with the role of the wife. This tendency is quite significant in the light of research results that indicate that the spouses' perceived equality in the allocation of domestic task responsibilities may not only contribute to their experience of enhanced marital happiness, but may also minimise their experience of role overload (Piña \& Bengtson, 1993:902). This goes hand-in-hand with whether or not the dual-earner spouses define the division of labour as fair (Wilkie et al., 1998:577). Blair and Johnson 
(1992:580) mention in this regard that "... [the] perception of fairness has to do with more than relieving the wife of onerous labour, probably with the symbolic value of men's demonstration of their concern with fairness by contributing to household labour".

\subsubsection{Emotion work}

Thompson (1991:186) and Smit (2000a:259) mention that although men are marginally more involved in the performance of domestic tasks, rather than equally sharing the domestic workload, these men are more prone to support their wives in a symbolic way by doing emotion work. Emotion work refers to the active, rational attempt to manage one's own emotions to bring about a discernible facial, bodily and/or verbal 'display' in the endeavour to enhance the spouse's emotional well-being (Hochschild, 1979:561; Erickson, 1993:888). Traditionally, according to Erickson (1993:890), the performance of emotion work was embedded within the wife/mother's family responsibilities. Expressive qualities have, however, also become more manifest in the role of the husband/father, especially insofar as more men are actively becoming aware of the importance of the performance of emotion work vis-à-vis their wives. This is especially important in light of the possible relationship between the performance of emotion work and the enhancement of the experience of marital satisfaction (Smit, 2000a:655).

\subsubsection{Time management}

As a preventative measure against the experience of role overload, the implementation of time-management strategies such as sequencing and/or prioritising time investment in work and family activities and responsibilities can be invaluable (Johnson \& Mortimer, 2000:220). Theorists such as Googins (1991:42) and Becker and Moen (1999:1003) are of the opinion that the more successful the dual-earner couple's time management strategies, the more likely they will be to experience high levels of marital integration. It is, however, also important that provision is made in the couple's time schedules for both individual and familial recreation and leisure activities (Googins, 1991:42).

One of the ways in which time-management difficulties, due to the simultaneous incumbency of family and work roles, can be addressed is by accepting help from other family members (for example when grandparents keep an eye on their grandchildren, while the parents are working late). When discussing time management and the practical allocation of domestic labour in the household, I would like to stress the necessity to take into consideration the prevalence of domestic service in South Africa. A paid domestic worker may not only lighten the burden 
regarding time consuming domestic task obligations in the dual-earner household, but may also be involved in child-care activities, and therefore alleviate the couple's possible experience of role overload (Lewis, 1992:10).

\subsubsection{Commitment to growth in the marriage}

Although this variable is of cardinal importance in all marital relationships, it is even of more importance in the dual-earner family. I am of the opinion that regardless of the positive impact of all the other familyrelated intervening variables, if both the dual-earner spouses are not committed to growth in their marriage, the experience of a high level of marital integration and happiness will not be possible. Their commitment to "make their (dual-earner) marriage work", may become a mediating factor in the possible negative relationship between the labour-market participation of both spouses and the experience of marital integration (Gelles, 1995:242).

Apart from the family-related variables relating to the husband-wife relationship, a number of variables associated with the relationship between parent and child can also be of great importance.

\subsection{Family-related variables: the parent-child relationship}

The presence of children in the family brings about a number of additional intervening variables that may have a mediating influence on the dual-earner couple's marital quality.

\subsubsection{The parents' perception of the impact of parental labour-market participation on their children's well-being}

Many theorists such as Belsky and Eggebeen (1991:1083) believe that maternal employment may have negative effects on child well-being. In more recent studies, however, no significant negative relationship was found between either maternal or paternal employment and children's cognitive abilities (Parcel et al., 2000:190). Moen (1992:86) refers for example to research results indicating that children whose mothers are full-time employees are more likely to show independence and selfassurance than children with mothers who do not participate in the labour market. These findings may bring about a more positive attitude towards parental employment and may consequently facilitate a better workfamily fit in the dual-earner family. 


\subsubsection{The husband's participation in child-care responsibilities}

Theorists such as Lamb (1995:33) and Kalmijn (1999:409) have found that high levels of marital satisfaction are associated with high levels of paternal involvement in day-to-day child-care activities. Volling and Belsky (1991:472) and Smit (2000a:92) indicate in this regard that dualearner couples who share in child-care responsibilities experience higher levels of marital quality than those couples where only the wife is responsible for child-care. This can be attributed to the possibility that the spouses may take delight in each other's as well as their children's presence during activities where both parents participate in child-care. Due to time constraints, the dual-earner couple is usually unable, when it comes to child-care responsibilities, to cope on their own and is therefore compelled to make use of other forms of child-care assistance.

\subsubsection{Child-care}

In contrast to situations where high quality and affordable child-care is not readily available (Hofferth, 2000:136), the dual-earner couple may experience higher levels of mental well-being when they, according to Rowe (1978:98), adhere to the following principle regarding child-care: "... children are much likeliest to thrive if the parents are happy about their work and child-care decisions, and if the care takers are stable, responsive and consistent."

It is clear from the above discussion that the dual-earner couple's marital quality may be influenced by both conjugal and parental intervening variables. Apart from these variables there are also variables related to the working environment that may have a mediating influence on the relationship between the couple's labour-market participation and their experience of marital integration.

\subsection{Work-related variables}

Due to the fact that the spouses' occupational involvement plays such a central role in their dual-earner family lifestyle, I find it to be important, in the light of the spillover model, to focus on work-related intervening variables that may alleviate potential stress in the dual-earner family.

\subsubsection{Career involvement and ambition}

Contrary to the general perception that the spouses' high career ambition has a negative influence on their marital quality, theorists such as O'Neil and Greenberger (1994:109) and Smit (2000a:651) have found a complementary relationship between a high commitment to success in the work arena and a high commitment to growth in the marriage. Hence, 
according to Smit (2000a:67), the professional orientation and ambition of the dual-earner spouses may contribute positively to marital adjustment, while marital adjustment may also be conducive to positive functioning in the occupational environment. Related to career involvement and ambition is the spouses' perception of their experienced occupational stress and satisfaction.

\subsubsection{Occupational stress and satisfaction}

It is clear from the research done by Zimbler et al. (1985:68) that the experience of stress can affect the individual both positively and negatively. Quick and Quick (1984:154) are of the opinion that each individual has his/her own optimal stress level when it comes to so-called functional stress (or eustress). Eustress is associated with positive wellbeing, flexibility, adaptability and high performance levels. Once this optimal stress level is exceeded, the individual experiences the stress as a negative force and its influence as counter-productive.

It is these negative qualities associated with stress in the working environment that may have a detrimental effect on family relationships. Occupational stress, due to inter alia long working hours and undesirable working conditions (Moen, 1989:8) may, according to Hughes et al. (1992:34) and Bumpus et al. (1999:466), contribute to an escalation in marital conflict and arguments.

If the dual-earner spouses are, however, able to cope successfully with occupational stress (Barnett, 1994:647) or are experiencing high levels of occupational satisfaction, these positive qualities in the work sphere may have a spillover effect into the family environment. This positive spillover may, according to Hughes et al. (1992:40) and Pittman (1994:185), enhance the spouses' experience of marital quality and companionship.

\subsubsection{Organisational culture}

There is an increasing demand in society for employers to be more accommodating towards their employees' family responsibilities, without making any distinction between the employees on the basis of their gender. The closer the formal organisation move towards becoming a socalled family-friendly employer or a pro-family workplace, the more opportunities are created for equal parenting to take place in the (dualearner) family (Gerson, 1993:237). This positive family-orientated organisational culture is characterised in the first place by the availability of alternative (or flexible) employment patterns. These patterns include for example flexi-time; flexi-workplace; telecommuting; job-sharing and parttime work (Carter \& Carter, 1995:165; Becker \& Moen, 1999:1004). 
In the second place, in order to establish a pro-family organisational culture, it is important for an organisation to have a flexible parental policy. This policy must make provision for both on the one hand, parental leave (Sandberg \& Cornfield, 2000:167) and on the other hand, child-care facilities and/or assistance (Moen, 1992:111; Hofferth, 2000: 153). The smaller the so-called culture gap between the organisational culture and the employees' (strenuous) dual-earner lifestyle, the easier it will become for the dual-earner couple to establish a work-family fit that can be conducive to marital integration (Bowen \& Orthner, 1991:206; Smit, 2000a:75).

\section{Conclusion}

In order to maintain healthy marital and familial relationships, the dualearner couple needs to establish a workable work-family fit. This workfamily fit is imperative for the experience of marital integration, as is clear from the following statement made by Pittman (1994:203): "Work-family fit directly, and negatively, predicted marital tension. As fit increased, marital tension declined."

A work-family fit is of even more importance in the light of the fact that family roles in many societies, as in the case of South Africa, are in a process of (necessary) change. It is highly debatable whether these changes in gender and marital roles (especially the way in which they have changed in the dual-earner family) may be considered an antecedent factor for family decline, as voiced by Popenoe (1993). I believe that rather than these changes being elements of the "end-of-the-line family", to use Popenoe's (1993:540) concept, it may be indicative of adaptation to a changing social environment, which occurs to preserve and strengthen families.

Looking at the situation of the dual-earner family as a whole, there is evidence that the changes regarding gender and marital roles, such as the husband/father's increased involvement in the domestic environment and the wife/mother's labour-market participation, do not necessarily have a detrimental effect on family life as voiced by the supporters of the spillover model. This finding necessitates the theoretical revision of this spillover model, i.e. shifting the focus away from a simple negative cause-and-effect relationship to that of a model which takes into consideration the possible existence of a multitude of variables that may mediate the relationship between the labour-market participation of both spouses and the nature of the quality of the marital relationship. It is furthermore important to stress the positive spillover that may take place between the 
work and family milieu, and which may enhance the quality of relationships and role performance in both these life spheres.

The crucial question asked in the title of this article, i.e. is there hope for marital happiness in the dual-earner family, may be answered in the affirmative based on the way work-related and family-related intervening variables interact to alleviate the stress caused by the dual-earner family lifestyle and even contribute to an increased experience of marital integration, marital happiness and quality of family life.

\section{Bibliography}

BARNETT, R.C. 1994. Home-to-Work Spillover Revisited: A Study of Full-Time Employed Women in Dual-Earner Couples. Journal of Marriage and the Family, 56(3):647-656.

BECKER, P.E. \& MOEN, P. 1999. Scaling Back: Dual-Earner Couples' Work-Family Strategies. Journal of Marriage and the Family, 61(4):995-1007.

BELSKY, E. \& EGGEBEEN, D. 1991. Early and Extensive Maternal Employment and Young Children's Socio-emotional Development: Children of the National Longitudinal Survey of Youth. Journal of Marriage and the Family, 53(4):10831110.

BENOKRAITIS, N.V. 1996. Marriages and Families. Changes, Choices and Constraints. Upper Saddle River : Prentice Hall.

BERGER, M., FOSTER, M. \& WALLSTON, B.S. 1978. Finding Two Jobs. (In Rapoport, R. \& Rapoport, R.N., eds. Working Couples. London : Routledge \& Kegan Paul. p. 23-35.)

BILLER, H.B. 1995. Preventing Paternal Deprivation. (In Shapiro, J.L., Diamond, M.J. \& Greenberg, M.G., eds. Becoming a Father. New York : Springer Publishing Company. p. 72-82.)

BLAIR, S.L. \& JOHNSON, M.P. 1992. Wives' Perceptions of the Fairness of the Division of Household Labour. Journal of Marriage and the Family, 54(3):570581.

BOWEN, G.L. \& ORTHNER, D.K. 1991. Effects of Organizational Culture on Fatherhood. (In Bozett, F.W. \& Hanson, S.M.H., eds. Fatherhood and Families in Cultural Context. New York : Springer Publishing Company. p. 187-217).

BRAYFIELD, A.A. 1992. Employment Resources and Housework in Canada. Journal of Marriage and the Family, 54(1):19-30.

BUMPUS, M.F., CROUTER, A.C. \& McHALE, S.M. 1999. Work Demands of DualEarner Couples: Implications for Parents' Knowledge About Children's Daily Lives in Middle Childhood. Journal of Marriage and the Family, 61(2):465-475.

CARLSON, C. 1990. Perspectives on the Family: History, Class and Feminism. California : Wadsworth.

CARTER, J.C. \& CARTER, J.D. 1995. He Works. She Works. Successful Strategies for Working Couples. New York : Amacom.

COOK, A.H. 1992. Can Work Requirements Accommodate to the Needs of DualEarner Families? (In Lewis, S., Izraeli, D.N. \& Hootsman, H., eds. Dual-Earner Families: International Perspectives. London : Sage Publications. p. 204-220.)

CROUTER, A.C., PERRY-JENKINS, M., HUSTON, T.L. \& McHALE, S.M. 1987. Processes underlying father involvement in dual-earner and single-earner families. Developmental Psychology, 23(3):431-440. 
DAVIDSON, M. \& COOPER, C. 1983. Stress and the Woman Manager. Oxford : Robertson.

EDWARDS, M.E. 2001. Uncertainty and the Rise of the Work-Family Dilemma. Journal of Marriage and the Family, 63(1):183-196.

EDWARDS, J.N., FULLER, T.D., VORAKITPHOKATORN, S. \& SERMSRI, S. 1992. Female Employment and Marital Instability: Evidence from Thailand. Journal of Marriage and the Family, 54(1):59-68.

ERICKSON, R.J. 1993. Reconceptualizing Family Work: The Effect of Emotion Work on Perceptions of Marital Quality. Journal of Marriage and the Family, 55(4):888900.

GELLES, R.J. 1995. Contemporary Families. A Sociological View. London : Sage Publications.

GERSON, K. 1993. No Man's Land: Men's Changing Commitments to Family and Work. New York : Basic Books.

GOOGINS, B.K. 1991. Work/Family Conflicts: Private Lives - Public Responses. New York: Auburn House.

GREENSTEIN, T.N. 2000. Economic Dependence, Gender and the Division of Labor in the Home: A Replication and Extension. Journal of Marriage and the Family, 62(2):322-335.

GRISWOLD, R.L. 1993. Fatherhood in America. A History. New York : Basic Books.

HANTRAIS, L. 1990. Managing Professional and Family Life. Brookfield : Dartmouth.

HANDY, C. 1978. Going against the Grain: Working Couples and Greedy Occupations. (In Rapoport, R. \& Rapoport, R.N., eds. Working Couples. London : Routledge \& Kegan Paul. p. 36-46.)

HOCHSCHILD, A.R. 1979. Emotion work, feeling rules, and social structure. American Journal of Sociology, 85(3):551-575.

HOLMSTROM, L.L. 1972. The Two Career Family. Cambridge : Schenkman.

HOFFERTH, S.L. 2000. Effects of Public and Private Policies on Working after Childbirth. (In Parcel, T.C. \& Cornfield, D.B., eds. Working \& Family. Research Informing Policy. Thousand Oaks : Sage Publications. p. 131-159.)

HUGHES, D., GALINSKY, E. \& MORRIS, A. 1992. The Effects of Job Characteristics on Marital Quality. Journal of Marriage and the Family, 54(1):31-42.

JOHNSON, M.K. \& MORTIMER, J.T. 2000. Work-Family Orientations and Attainments in the Early Life Course. (In Parcel, T.C. \& Cornfield, D.B., eds. Working \& Family. Research Informing Policy. Thousand Oaks : Sage Publications. p. 215248.)

JORDAN, C., COBB, N. \& McCULLY, R. 1989. Clinical Issues of the Dual-Career Couple. Social Work, 34(1):29-32.

KALMIJN, M. 1999. Father Involvement in Childrearing and the Perceived Stability of Marriage. Journal of Marriage and the Family, 61(2):409-421.

KLUWER, E.S., HEESINK, J.A.M. \& VAN DE VLIERT, E. 1997. The Marital Dynamics of Conflict over the Division of Labor. Journal of Marriage and the Family, 59(3):635-653.

LAMB, M.E. 1995. The Changing Roles of Fathers. (In Shapiro, J.L., Diamond, M.J. \& Greenberg, M.G., eds. Becoming a Father. New York : Springer. p. 18-35.)

LEWIS, S. 1992. Introduction: Dual-Earner Families in Context. (In Lewis, S., Izraeli, D.N. \& Hootsmans, H., eds. Dual-Earner Families: International Perspectives. London : Sage. p. 1-18.

LONG, C.B. \& KAHN, S.E. 1993. Women, Work, and, Coping. A Multidisciplinary Approach to Workplace Stress. Montreal : McGill-Queen's University Press. 
MACONACHIE, M. 1992. The allocation of domestic tasks by white married couples. South African Journal of Sociology, 23(4):112-118.

MCGRATH, E., KEITA, G.P., STRICKLAND, B.R. \& RUSSO, N. 1993. Women and Depression: Risk Factors and Treatment Issues. Washington DC : American Psychological Association.

MENAGHAN, E.G. \& PARCEL, T.L. 1990. Parental Employment and the Family Life: Research in the 1980s. Journal of Marriage and the Family, 52(4):1079-1098.

MOEN, P. 1989. Working Parents: Transformations in Gender Roles and Public Policies in Sweden. London: Adamantine.

MOEN, P. 1992. Women's Two Roles: A Contemporary Dilemma. New York : Auburn House.

O'NEIL, R. \& GREENBERGER, E. 1994. Patterns of Commitment to Work and Parenting: Implications for Role Strain. Journal of Marriage and the Family, 56(1):101-118.

PADEN, S.L. \& BUEHLER, C. 1995. Coping with the Dual-Income Lifestyle. Journal of Marriage and the Family, 57(1):101-110.

PARCEL, T.L., NICKOLL, R.A. \& DUFUR, M.J. 2000. The Effects of Parental Work and Maternal Nonemployment on Children's Reading and Math Achievement. (In Parcel, T.C. \& Cornfield, D.B., eds. Working \& Family. Research Informing Policy. Thousand Oaks : Sage. p. 189-213.)

PERRY-JENKINS, M., REPETTI, R.L. \& CROUTER, A.C. 2000. Work and Family in the 1990s. Journal of Marriage and the Family, 62(4):981-998.

PIÑA, D.L. \& BENGTSON, V.L. 1993. The Division of Household Labour and Wives' Happiness: Ideology, Employment, and Perceptions of Support. Journal of Marriage and the Family, 55(4):901-912.

PITTMAN, J.F. 1994. Work/Family Fit as a Mediator of Work Factors on Marital Tension: Evidence from the Interface of Greedy Institutions. Human Relations, 47(2):183-209.

POPENOE, D. 1993. American Family Decline, 1960-1990: A Review and Appraisal. Journal of Marriage and the Family, 55(3):527-542.

QUICK, J.C. \& QUICK, J.D. 1984. Organisational Stress and Preventative Management. New York: McGraw-Hill.

ROWE, M. 1978. Choosing Child Care: Many Options. (In Rapoport, R. \& Rapoport, R.N., eds. Working Couples. London : Routledge \& Kegan Paul. p. 89-99.)

SAFILIOS-ROTHSCHILD, C. \& DIJKERS, M. 1978. Handling Unconventional Asymmetries. (In Rapoport, R. \& Rapoport, R.N., eds. Working Couples. London : Routledge \& Kegan Paul. p. 62-73.)

SANDBERG, J.C. \& CORNFIELD, D.B. 2000. Returning to Work. The Impact of Gender, Family and Work on Terminating a Family and Medical Leave. (In Parcel, T.C. \& Cornfield, D.B., eds. Working \& Family. Research Informing Policy. Thousand Oaks : Sage. p. 161-184.)

SEARS, H.M. \& GALAMBOS, N.L. 1992. Women's Work Conditions and Marital Adjustment in Two-Earner Couples: A Structural Model. Journal of Marriage and the Family, 54(4):789-797.

SEKARAN, U. 1986. Dual-Career Families. San Francisco : Jossey-Bass.

SMIT, R. 2000a. Die veranderende rol van die man in die dubbelinkomstegesin. Johannesburg : Rand Afrikaans University. (Doctoral Dissertation.)

SMIT, R. 2000b. The Husband's Perception of his Changing Role in the Dual-Earner Family: The South African Experience of the White Afrikaner Husband/Father. (In Harvey, C.D.H., ed. Walking a Tightrope: Meeting the Challenges of Work and Family. London : Ashgate. p. 69-73.) 
THOMPSON, L. 1991. Family Work: Women's Sense of Fairness. Journal of Family Issues, 12(2):181-196.

VANNOY, A. \& PHILLIBER, W.W. 1992. Wife's Employment and Quality of Marriage. Journal of Marriage and the Family, 54(2):387-398.

VOLLING, B.L. \& BELSKY, J. 1991. Multiple Determinants of Father Involvement during Infancy in Dual-Earner Families. Journal of Marriage and the Family, 53(2):461-474.

WIERSMA, U.J. 1994. A Taxonomy of Behavioral Strategies for Coping with WorkHome Role Conflict. Human Relations, 47(2):211-221.

WILKIE, J.R., FERREE, M.M. \& RATCLIFF, K.S. 1998. Gender and Fairness: Marital Satisfaction in Two-Earner Couples. Journal of Marriage and the Family, 60(3):577-594.

ZIMBLER, A., SOLOMAN, C., YOM YOV, C. \& GRUDZ, C. 1985. Conquering Stress. Johannesburg : Divaris Stein.

\section{Key concepts:}

dual-earner family

husband-wife relationship

marital quality

work-family spillover

\section{Kernbegrippe:}

dubbelinkomstegesin

huwelikskwaliteit

man-vrouverhouding

werk-gesin-oorloop 